\title{
Cytokinetic and structural responses of the rat small intestine to riboflavin depletion
}

\author{
BY E. A. WILLIAMS 1 , R. D. E. RUMSEY² AND H. J. POWERS ${ }^{1 *}$ \\ ${ }^{1}$ University Department of Paediatrics, Sheffield Children's Hospital, Western Bank, Sheffield \\ S10 $2 T H$ \\ ${ }^{2}$ Department of Biomedical Science, University of Sheffield S10 2TN
}

(Received 25 November 1994-Revised 19 April 1995 - Accepted 23 May 1995)

\begin{abstract}
The impaired absorption and metabolism of Fe seen in ribofiavin deficiency is attributed, at least in part, to a hyperproliferative response in the small intestine, associated with an altered morphology. Studies were conducted in female weanling Wistar rats to explore further the effect of riboflavin deficiency on the cytokinetics and structure of the small intestine. Feeding a riboflavin-deficient diet for 8 weeks from weaning resulted in a significantly lower villus number, a significant increase in villus length and an increased rate of transit of enterocytes along the villi, compared with weight-matched controls. A second experiment focused on the 3 weeks after weaning and showed that riboflavin deficiency inhibits the increase in villus number observed in control animals over this period. We suggest that riboflavin deficiency induced at weaning impairs the normal increase in villus number and that prolonged deficiency leads to an adaptive increase in length of villi and depth of crypts.
\end{abstract}

Riboflavin: Cytokinetics: Small intestine: Villus number

Studies in man have shown that riboflavin deficiency can impair the handling of Fe (Powers et al. 1983; Fairweather-Tait et al. 1992). Further investigations in rats have demonstrated that riboflavin deficiency induced from weaning leads to reduced Fe absorption and increased gastrointestinal Fe loss (Powers et al. 1991). Recent investigations into the mechanism for this effect have revealed an increase in the crypt-cell production rate in the duodenum, and increased crypt (Powers et al. 1993) and villus dimensions (Williams et al. 1995 ) in response to riboflavin deficiency at weaning.

The purpose of the current study was to establish whether the increased crypt-cell production rate seen in riboflavin deficiency influences the rate of transit of cells from the site of production within the crypt along the villus towards the lumen. Changes in transit time would have implications for both the functional maturity of enterocytes on the villi and the rate of exfoliation from the villi.

We have previously reported that despite villus-cell hyperplasia the total mucosal DNA content of the small intestine is unaltered by 5 weeks of feeding a riboflavin-deficient diet (Williams et al. 1995). If riboflavin deficiency were associated with a smaller villus number then villus-cell hyperplasia would not necessarily lead to an increased mucosal DNA content of the small intestine. We have counted villus number in the duodenum during the course of riboflavin deficiency in order to resolve this apparent anomaly.

\section{MATERIALS AND METHODS}

Two experiments were conducted, the first to establish the effect of riboflavin deficiency on the rate of cell transit along the villi, and the total villus number in the upper small intestine

$$
\text { * For reprints. }
$$


and the second to investigate the change in villus number as riboflavin depletion progresses. Female weanling Wistar rats (Sheffield strain) were weaned onto either a riboflavindeficient or a complete diet. The riboflavin-deficient group received a basal diet comprising $(\mathrm{g} / \mathrm{kg}$ ): arachis oil 30 , sucrose 700 , casein 200 (containing $0.52 \mathrm{mg}$ riboflavin $/ \mathrm{kg} \mathrm{diet}$ ), a riboflavin-free vitamin mixture and Briggs salt mixture (Seaford Laboratories, Seaford, East Sussex), (Powers, 1987). The control animals received a similar diet but supplemented with $15 \mathrm{mg}$ riboflavin $/ \mathrm{kg}$ diet. At the beginning of each experiment weanling rats were weighed and paired by weight, for allocation to a deficient or a complete diet. The animals were individually housed in wire-bottomed cages to minimize coprophagy. Water was freely available to all the animals. Animals receiving the riboflavin-deficient diet were allowed access to feed ad lib. between 09.30 and 16.30 hours. Body weights and amounts of feed consumed were measured daily at 09.30 hours and the amount of feed given to the control animals was restricted in order to maintain weights equal to those of the riboflavindeficient partners. Control animals were allowed access to their feed over the same $7 \mathrm{~h}$ period as their riboflavin-deficient partners. A $12 \mathrm{~h}$ light-dark cycle was maintained between $08.00,20.00$ and 08.00 hours; animals were kept at an average temperature of $21^{\circ}$, and humidity of $45 \%$.

\section{Experiment 1}

Twenty-four female weanling Wistar rats were divided into two groups to receive either a riboflavin-deficient or a complete diet. Fasting blood samples were collected at the start of the experiment and at $14 \mathrm{~d}$ intervals, between 09.30 and 12.30 hours. Rats were lightly anaesthetized using an intraperitoneal injection of Hypnorm (Janssen Pharmaceuticals Ltd, Oxford, Oxon; $0.2 \mathrm{ml} / \mathrm{kg}$ body weight), and a lower limb was shaved to expose the saphenous vein for puncture. Blood $(80 \mu \mathrm{l})$ was collected into heparinized tubes, and kept on ice for a maximum of $3 \mathrm{~h}$ before processing. Erythrocytes were separated by centrifugation, washed three times in an equal volume of isotonic saline $(9 \mathrm{~g} \mathrm{NaCl} / 1)$, and stored at $-20^{\circ}$ in three volumes of distilled water. The haemolysate was used for the measurement of riboflavin status, which was expressed in terms of the activation coefficient (EGRAC) for the enzyme erythrocyte glutathione reductase $(E C$ 1.6.4.2). The enzyme activity was measured spectrophotometrically using the Cobas Bio Autoanalyser (Roche Diagnostics, Welwyn Garden City, Herts), (Powers et al. 1983).

The rats were maintained on their diets for 8 weeks. Before the day of kill, food was removed as usual at 16.30 hours and weight-matched pairs were given an intraperitoneal injection of bromodeoxyuridine $(50 \mathrm{mg} / \mathrm{kg}$ body weight; Sigma Chemical Co., Poole, Dorset) in turn at intervals of $15 \mathrm{~min}$ between 16.45 and 19.30 hours. $17 \mathrm{~h}$ later, after an overnight fast, the rats were killed by cervical dislocation, in pair sequence, at intervals of $15 \mathrm{~min}$. Upon kill the thoracic cavity was opened and a maximum amount of blood collected by cardiac puncture; a portion was processed for the measurement of EGRAC. The abdomen was opened up, the liver removed, washed in saline, blotted dry, and stored at $-20^{\circ}$ for the fluorimetric measurement of liver flavins (Bessey et al. 1949). The small intestine was carefully dissected out of the animals and the length measured. A $40 \mathrm{~mm}$ length of duodenum was cut $20 \mathrm{~mm}$ distal to the pylorus, divided into two $20 \mathrm{~mm}$ segments, opened along the mesentery, pinned out onto dental wax and fixed overnight in $40 \mathrm{~g} / 1$ paraformaldehyde prepared in 0.01 M-phosphate-buffered saline (PBS) pH 7.4. After $24 \mathrm{~h}$ the proximal segment was embedded in paraffin wax by dehydrating the tissue through a series of alcohol solutions, placing it in xylene and then embedding it within melted paraffin wax, which hardens on cooling. Longitudinal sections ( $5 \mu \mathrm{m}$ thick) were cut from the paraffin wax block and subsequently used for the immunohistochemical detection of bromodeoxyuridine (Gratzner, 1982). After fixing overnight, the $10 \mathrm{~mm}$ distal segment of 
duodenum was transferred into $700 \mathrm{ml} / 1$ ethanol and used in the calculation of villus number.

Calculation of villus number. The $10 \mathrm{~mm}$ segment of duodenum was stained using the Feulgen staining reaction (Wimber \& Lamberton, 1963) to allow the total number of villi to be counted. The piece of tissue was placed on a microscope slide, mucosal side uppermost with a drop of acetic acid $(450 \mathrm{ml} / \mathrm{l})$, secured with a glass coverslip and viewed under a light microscope. The natural arrangement of villi in parallel rows at right angles to the direction of luminal flow allowed the number of villi per $10 \mathrm{~mm}$ length to be calculated. To ensure accuracy of counts, the total number of villus rows and the number of villi per row were counted in five separate counts on the same piece of duodenum. The mean number of villus rows and the mean number of villi per row were then used to calculate the total number of villi per $10 \mathrm{~mm}$ length of intestine.

Measurement of the enterocyte transit time. Sections were deparaffinized by immersing the slides in two changes of xylene and then rehydrating the tissue by passing through a series of progressively weaker ethanol solutions from $1000 \mathrm{ml} / 1$ to water. Bromodeoxyuridine-labelled cells were detected in the tissue sections using a modification of the method described by Wynford-Thomas \& Williams (1986). Tissue sections were immersed in $3 \mathrm{ml} / 1 \mathrm{H}_{2} \mathrm{O}_{2}$ prepared in $500 \mathrm{ml} / \mathrm{l}$ methanol to block endogenous peroxidase activity and washed in PBS. Each section was covered with $50 \mu 1$ of a $0.4 \mathrm{~g} / 1$ solution of pepsin $(E C$ 3.4.23.1) prepared in $0.1 \mathrm{M}-\mathrm{HCl}$, for $25 \mathrm{~min}$ and incubated in $2 \mathrm{M}-\mathrm{HCl}$ for $30 \mathrm{~min}$ at $37^{\circ}$ to denature the DNA. Sections were neutralized with $0 \cdot 1 \mathrm{M}$-di-sodium tetraborate and after two $5 \mathrm{~min}$ washes in PBS were treated with $150 \mu \mathrm{l}$ normal horse serum (Vector Laboratories, Peterborough, Cambs) in $10 \mathrm{ml}$ PBS for $20 \mathrm{~min}$ to block any nonspecific endogenous binding sites to which the subsequent secondary biotinylated antibody (made in horse) may bind. A mouse monoclonal primary antibody to bromodeoxyuridine (Gratzner, 1982) was applied overnight at $4^{\circ}$ at a dilution of 1 in 50 in the horse serum. After two $5 \mathrm{~min}$ washes in PBS the sections were incubated at room temperature for $60 \mathrm{~min}$ with $50 \mu \mathrm{l}$ secondary biotinylated anti-mouse antibody conjugated to horseradish peroxidase (EC 1.11.1.7) at a dilution of 1 in 100 in horse serum. After two 5 min washes in PBS the sections were incubated with Avidin Biotinylated Biotin Complex (Vector Laboratories) for $30 \mathrm{~min}$ and after two further $5 \mathrm{~min}$ washes with PBS the sites of antibody attachment were identified by a $15 \mathrm{~min}$ incubation with a peroxidase substrate (amino-ethyl carbazole) kit (Vector Laboratories). The sections were washed for $5 \mathrm{~min}$ in water before mounting with glycerol.

The positively stained bromodeoxyuridine-containing cells were identified under the light microscope. The length of the villus from the crypt-villus junction to the villus tip, and the distance travelled by the leading cohort of stained (newly replicated) cells furthest away from the crypt-villus junction were measured using an image analysis system (Seescan Analytical Services Ltd, Cambridge, Cambs) on complete, well orientated villi sections viewed under a light microscope (Jenaval, Zeiss). Five measurements were made on each slide for villus length and the distance travelled by newly replicated cells.

\section{Experiment 2}

Thirty-six female 21-d-old Wistar rats were allocated to one of two dietary groups; riboflavin-deficient and weight-matched controls as described previously. Twelve animals, six from each group, were killed by cervical dislocation on days 7,14 and 21 of receiving the experimental diets. A further six rats were killed on (experimental) day 0 without receiving any experimental diet, to provide baseline values. Blood samples were collected on (experimental) day 0 and, by cardiac puncture, at the time of kill, as described for Expt 
1. The liver was removed, washed in saline, blotted dry, and stored at $-20^{\circ}$ for the measurement of liver flavins (Bessey et al. 1949). The small intestine was carefully dissected out of the animal and its length measured. A $20 \mathrm{~mm}$ section of duodenum cut $20 \mathrm{~mm}$ distal to the pylorus was opened along the mesentery, pinned out onto dental wax, fixed overnight in ethanol-glacial acetic acid $(75: 25, \mathrm{v} / \mathrm{v})$ and transferred to $700 \mathrm{ml} / 1$ ethanol. The tissue was then stained using the Feulgen reaction and the villus number estimated in a $10 \mathrm{~mm}$ section of duodenum as described above. Individual villi and crypts were carefully dissected out and their lengths and depths measured. The lumen of the remainder of the small intestine was flushed out with saline, the mucosa scraped away from the submucosa and muscle (Williamson et al. 1978) and frozen at $-20^{\circ}$ for the subsequent estimation of total mucosal DNA (Munro \& Fleck, 1966).

\section{Statistical analysis}

Experiment 1. A paired $t$ test was used to investigate the effects of diet on body weight at the time of kill, average daily food consumption, weight gain/g food consumed and liver flavins. Morphological variables, cell transit rate along the villi and villus number were also compared using a paired $t$ test. A two-way ANOVA was performed to investigate the effects of diet and time on riboflavin status, as measured by EGRAC.

Experiment 2. A paired $t$ test was used to investigate the effects of diet on body weight at the time of kill, average daily food consumption, weight gain/g food consumed and liver flavins. Riboflavin status at the time of kill, measured as liver flavins and EGRAC values, was also compared using paired $t$ tests. A two-way ANOVA was used to investigate the effects of time and diet on villus number and total mucosal DNA. When significant $F$ ratios were found, individual means were compared with the Scheffé test $(P<0 \cdot 05)$.

\section{RESULTS}

\section{Experiment 1}

The mean body weights at the start of the experiment were 64.3 (SE 3.61) g and 63.6 (SE 3.09) g for the riboflavin-deficient animals and weight-matched controls respectively. This weight-matching was maintained throughout the experiment. At the time of kill the mean body weights for the riboflavin-deficient animals and weight-matched controls were $151 \cdot 3$ (SE 5.15) $\mathrm{g}$ and $154 \cdot 1$ (SE 5.09) $\mathrm{g}$ respectively; these were not significantly different. The riboflavin-deficient group consumed 11.9 (SE 0.26) $\mathrm{g}$ diet/d and had a mean weight gain of 0.13 (SE 0.004) g/g diet compared with a food consumption of 11.3 (SE 0.19) $\mathrm{g} / \mathrm{d}$ and a weight gain of 0.14 (SE 0.004$) \mathrm{g} / \mathrm{g}$ diet in the weight-matched group. Food consumption was not different between the two groups but weight gain per $\mathrm{g}$ diet was significantly lower in the riboflavin-deficient group $(P<0.05)$.

At the start of the experiment all animals had normal riboflavin status; the mean EGRAC value of the riboflavin-deficient group was 1.22 (SE 0.035) compared with 1.29 (SE 0.032) in the weight-matched group. The riboflavin status of the group fed on the depleted diet deteriorated throughout the course of the experiment. A two-way ANOVA revealed significant effects of $\operatorname{diet}(P<0.001)$ and time $(P<0.001)$ on riboflavin status and a significant interaction between these two variables $(P<0.001)$. Biochemical ariboflavinosis (EGRAC $\geqslant 1.4$ ) was evident in all animals in the riboflavin-deficient group by day 14. This deficiency was maintained for the remainder of the experiment. Final mean EGRAC values in the riboflavin-deficient and weight-matched control groups were 1.89 (SE 0.075) and 1.19 (SE 0.018) respectively. Concentrations of liver flavins at the time of kill 
Table 1. Expt 1. Effects of riboflavin depletion on villus morphology and cell transit in

(Mean values with their standard errors)

\begin{tabular}{|c|c|c|c|c|c|}
\hline & \multicolumn{2}{|c|}{$\begin{array}{l}\text { Riboflavin-deficient } \\
\text { (n 12) }\end{array}$} & \multicolumn{2}{|c|}{$\begin{array}{l}\text { Weight-matched } \\
\qquad(n 12)\end{array}$} & \multirow{2}{*}{$\begin{array}{c}\text { Statistical } \\
\text { significance } \\
\text { of difference } \dagger \\
P=\end{array}$} \\
\hline & Mean & SEM & Mean & SEM & \\
\hline Villus length $(\mu \mathrm{m})$ & $557 \cdot 1$ & $8 \cdot 38$ & $468 \cdot 4$ & 9.97 & 0.000 \\
\hline Leading edge $(\mu \mathrm{m}) \ddagger$ & $122 \cdot 2$ & $9 \cdot 20$ & $59 \cdot 3$ & $4 \cdot 43$ & 0.000 \\
\hline Rate $(\mu \mathrm{m} / \mathrm{h}) \S$ & 7.2 & 0.54 & 3.5 & 0.25 & 0.000 \\
\hline$\%$ of villus length $\|$ & 22 & 1.7 & 12 & 0.9 & 0.000 \\
\hline $\begin{array}{l}\text { Number of villi } / 10 \mathrm{~mm} \\
\text { length of duodenum }\end{array}$ & 1335 & $115 \cdot 4$ & 1780 & 88.4 & 0.004 \\
\hline
\end{tabular}

* For details of diets and procedures see pp. 315-317.

$\dagger$ Significance of the $t$ statistic for comparison of means (paired $t$ test).

Distance of the leading edge from the base of the villus.

$\S$ Rate of transit of the leading edge.

If Distance travelled by the leading edge as a percentage of the total villus length.

were significantly lower in the riboflavin-deficient group, with a mean FAD value of $15 \cdot 1$ (SE 0.43) $\mu \mathrm{g} / \mathrm{g}$ compared with a mean value of 26.9 (SE 0.68) $\mu \mathrm{g} / \mathrm{g}$ in the weight-matched controls $(P<0.001)$.

Table 1 shows the results for the villus morphology, enterocyte transit and villus number. Villus length in the riboflavin-deficient group was significantly increased relative to the weight-matched controls. The leading edge of the cohort of labelled cells had moved a greater distance along the villi in the riboflavin-deficient group compared with the weightmatched group. Despite the relatively longer villi, the enterocytes had covered a greater percentage of the villi in the riboflavin-deficient animals than in the control animals. There was an approximate twofold increase in the rate of transit of cells along the villi in the riboflavin-deficient group. In addition, there were significantly fewer villi per $10 \mathrm{~mm}$ length of duodenum in the riboflavin-deficient animals compared with the control animals.

\section{Experiment 2}

Table 2 shows the mean food consumption/d, weight gain/g diet and final body weight for each of the experimental groups. Mean daily food consumption was higher and weight gain/g diet was significantly lower in the riboflavin-deficient animals compared with the controls on all points of comparison. There was no difference in the body weights between the two dietary groups at any time of kill.

All rats fed on the riboflavin-deficient diet were biochemically deficient in riboflavin at the time of death and had significantly higher EGRAC values than the weight-matched controls (Table 3). Similarly, liver FAD concentrations were significantly lower in the riboflavin-deficient group than the controls at all points of measurement.

Table 4 shows the effect of riboflavin deficiency on villus number and total mucosal DNA content of the small intestine. Two-way ANOVA identified significant effects of time and diet on total mucosal DNA content of the small intestine and the number of villi in a $10 \mathrm{~mm}$ length of duodenum. The interaction of these two factors was only significant for mucosal DNA $(P=0.000)$. Post-hoc analysis identified a significant increase from baseline values in the number of villi in a $10 \mathrm{~mm}$ length of duodenum in the control animals by $21 \mathrm{~d}$ post 


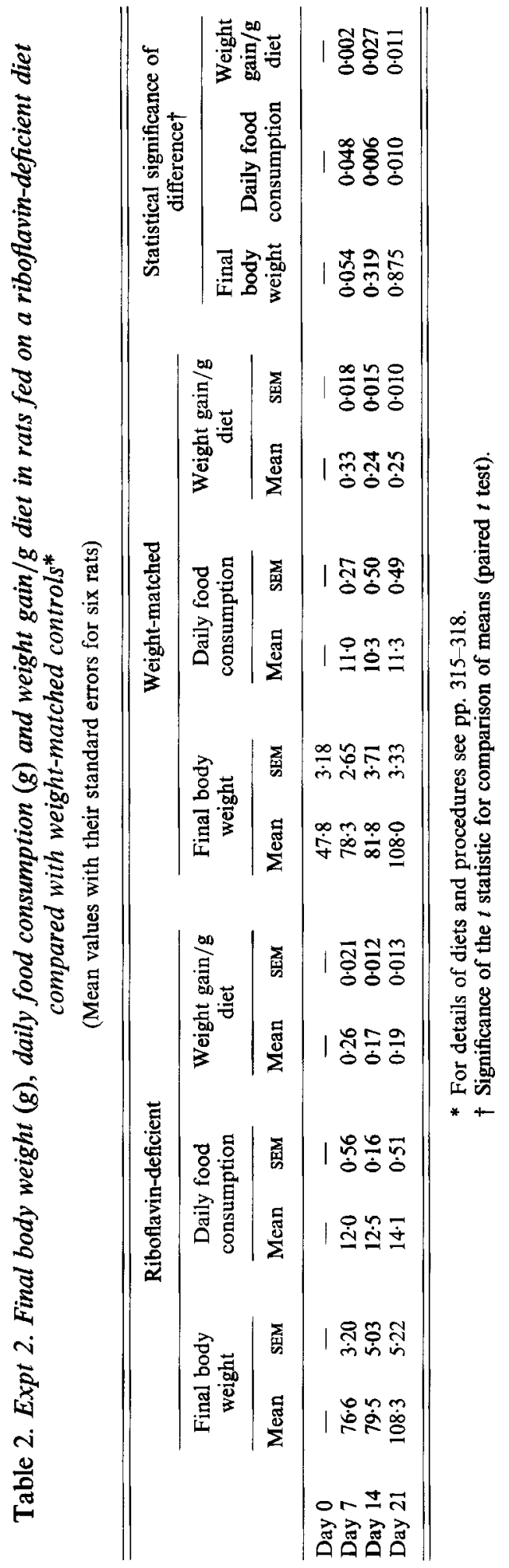


Table 3. Expt 2. Erythrocyte glutathione reductase (EC 1.6.4.2) activation coefficient $(E G R A C)$ values and liver $F A D$ concentrations $(\mu \mathrm{g} / \mathrm{g}$ wet weight) in rats fed on a riboflavindeficient diet compared with weight-matched controls*

(Mean values with their standard errors)

\begin{tabular}{|c|c|c|c|c|c|c|c|c|c|c|}
\hline & \multicolumn{4}{|c|}{$\begin{array}{l}\text { Riboflavin-deficient } \\
\qquad(n 6)\end{array}$} & \multicolumn{4}{|c|}{$\begin{array}{l}\text { Weight-matched } \\
(n 6)\end{array}$} & \multirow{2}{*}{\multicolumn{2}{|c|}{$\begin{array}{c}\text { Statistical } \\
\text { significance of } \\
\text { difference }{ }^{\dagger}\end{array}$}} \\
\hline & \multicolumn{2}{|c|}{ EGRAC } & \multicolumn{2}{|c|}{ FAD } & \multicolumn{2}{|c|}{ EGRAC } & \multicolumn{2}{|c|}{ FAD } & & \\
\hline & Mean & SEM & Mean & SEM & Mean & SEM & Mean & SEM & EGRAC & FAD \\
\hline Day 0 & - & - & 一 & - & $1 \cdot 21$ & 0.050 & $18 \cdot 7$ & 0.52 & 一 & - \\
\hline Day 7 & 1.96 & $0 \cdot 124$ & $12 \cdot 5$ & $0 \cdot 70$ & $1 \cdot 15$ & 0.043 & $18 \cdot 5$ & 0.52 & 0.0026 & 0.0029 \\
\hline Day 14 & 2.57 & 0.153 & $15 \cdot 3$ & 0.58 & $1 \cdot 19$ & 0.051 & $24 \cdot 4$ & $2 \cdot 21$ & 0.0002 & 0.0089 \\
\hline Day 21 & $2 \cdot 65$ & $0 \cdot 169$ & $16 \cdot 6$ & 0.90 & $1 \cdot 28$ & 0.072 & 27.9 & $1 \cdot 20$ & 0.0012 & 0.0002 \\
\hline
\end{tabular}

* For details of diets and procedures see pp. 315-318.

$\uparrow$ Significance of the $t$ statistic for comparison of means (paired $t$ test).

Table 4. Villus number within a $10 \mathrm{~mm}$ length of duodenum and the total mucosal DNA content of the small intestine of rats fed on a riboflavin-deficient diet compared with weightmatched controls $\dagger$

\begin{tabular}{|c|c|c|c|c|c|c|c|c|}
\hline & \multicolumn{2}{|c|}{ Villus number } & & & \multicolumn{2}{|c|}{$\begin{array}{l}\text { Total mucosal DNA } \\
(\mu \mathrm{g})\end{array}$} & \multirow{2}{*}{\multicolumn{2}{|c|}{$\begin{array}{c}\text { Statistical } \\
\text { significance of } \\
\text { difference: } P=\end{array}$}} \\
\hline & \multirow{2}{*}{$\begin{array}{c}\text { Riboflavin- } \\
\text { deficient } \\
(n 6) \\
\text { Mean }\end{array}$} & \multirow{2}{*}{$\begin{array}{c}\text { Weight- } \\
\text { matched } \\
(n 6) \\
\text { Mean }\end{array}$} & \multicolumn{2}{|c|}{$\begin{array}{c}\text { Statistical } \\
\text { significance of } \\
\text { difference: } P=\end{array}$} & \multirow{2}{*}{$\begin{array}{c}\text { Riboflavin- } \\
\text { deficient } \\
(n 6) \\
\text { Mean }\end{array}$} & \multirow{2}{*}{$\begin{array}{l}\text { Weight- } \\
\text { matched } \\
(n 6) \\
\text { Mean }\end{array}$} & & \\
\hline & & & Diet & Time & & & Diet & Time \\
\hline Day 0 & - & 1462 & 0.000 & 0.035 & - & $6 \cdot 6$ & 0.000 & 0.000 \\
\hline Day 7 & 1414 & 1909 & & & 8.2 & $11 \cdot 6^{*}$ & & \\
\hline Day 14 & 1390 & 1713 & & & $7 \cdot 4$ & $10 \cdot 9 *$ & & \\
\hline Day 21 & 1496 & $2083^{*}$ & & & $9 \cdot 1^{*}$ & $9 \cdot 9 *$ & & \\
\hline Pooled SEM & $40^{\circ}$ & & & & 0.16 & & & \\
\hline
\end{tabular}

* Mean values were significantly different from day 0 value $(P<0.05)$ (Scheffé test)

$\dagger$ For details of diets and procedures see pp. 315-318.

weaning. No such increase was observed in the riboflavin-deficient animals. There was a significant correlation between the villus number and time post weaning in the control group, which was not evident in the riboflavin-deficient group $(r 0.507, P<0.01)$. By day 7 , animals in the control group showed a significant increase in mucosal DNA from values at weaning, which was maintained over the $21 \mathrm{~d}$ of study. By day 21 post-weaning a significant increase was also evident in the riboflavin-deficient animals.

Table 5 shows the results of the intestinal morphological measurements. A two-way ANOVA revealed significant effects of time and diet on crypt depth. There was no significant interaction of these two factors. By day 7 of receiving a riboflavin-deficient diet there was a significant increase in crypt depth above the value at weaning, which was maintained for the duration of the experiment. In contrast a significant increase in the crypt depth in the weight-matched animals was only evident on day 14 . There was an increase in villus length with time in the riboflavin-deficient group but this failed to reach significance. 
Table 5. Expt 2. Crypt depth and villus length in the small intestines of rats fed on a riboflavin-deficient diet compared with weight-matched controls $\dagger$

\begin{tabular}{|c|c|c|c|c|c|c|c|c|}
\hline & \multicolumn{2}{|c|}{ Crypt depth $(\mu \mathrm{m})$} & \multirow{2}{*}{\multicolumn{2}{|c|}{$\begin{array}{c}\text { Statistical } \\
\text { significance of } \\
\text { difference: } P=\end{array}$}} & \multicolumn{2}{|c|}{ Villus length $(\mu \mathrm{m})$} & \multirow{2}{*}{\multicolumn{2}{|c|}{$\begin{array}{c}\text { Statistical } \\
\text { significance of } \\
\text { difference: } P=\end{array}$}} \\
\hline & \multirow{2}{*}{$\begin{array}{c}\text { Riboflavin- } \\
\text { deficient } \\
(n 6) \\
\text { Mean }\end{array}$} & \multirow{2}{*}{$\begin{array}{l}\text { Weight- } \\
\text { matched } \\
(n 6) \\
\text { Mean }\end{array}$} & & & \multirow{2}{*}{$\begin{array}{c}\text { Riboflavin- } \\
\text { deficient } \\
(n 6) \\
\text { Mean }\end{array}$} & \multirow{2}{*}{$\begin{array}{c}\text { Weight- } \\
\text { matched } \\
(n 6) \\
\text { Mean }\end{array}$} & & \\
\hline & & & Diet & Time & & & Diet & Time \\
\hline Day 0 & - & $154 \cdot 4$ & 0.003 & 0.000 & - & 744.0 & 0.396 & 0.609 \\
\hline Day 7 & $309 \cdot 3 *$ & $232 \cdot 0$ & & & $790 \cdot 8$ & 775.8 & & \\
\hline Day 14 & $263 \cdot 5 *$ & $257.6 *$ & & & $814 \cdot 5$ & $770 \cdot 2$ & & \\
\hline Day 21 & $273 \cdot 5 *$ & 214.8 & & & $842 \cdot 3$ & 784.0 & & \\
\hline Pooled SEM & \multicolumn{2}{|c|}{$6 \cdot 16$} & & & \multicolumn{2}{|c|}{$18 \cdot 45$} & & \\
\hline
\end{tabular}

* Mean values were significantly different from day 0 value $(P<0.05)$ (Scheffé test).

$\dagger$ For details of diets and procedures see pp. 315318.

\section{DISCUSSION}

Riboflavin deficiency is associated with impaired Fe handling (Powers et al. 1991), increased crypt-cell production rate and altered intestinal morphology (Powers et al. 1993; Williams et al. 1995). These recent findings suggest a mechanism for the effects of riboflavin deficiency on Fe metabolism. The study described here shows that riboflavin deficiency significantly alters normal gut development within 3 weeks post-weaning by halting the increase in villus number. The subsequent increase in crypt and villus dimensions could be a direct effect of the increased crypt-cell production rate, which we suggest occurs as an adaptive response to the reduced villus number. Rapid cell production and an increased rate of cell transit will lead to a less mature population of enterocytes (Dowling, 1982).

An immediate and progressive increase in villus number in the duodenum in the period immediately following weaning, as we described here, has hitherto not been reported. Previous observers have found a slight but not significant change in villus number in the total small intestine of Wistar rats during growth from $60 \mathrm{~g}$ to $120 \mathrm{~g}$, which persists throughout adulthood (Clarke, 1972; Forrester, 1972). When small-intestinal length is taken into account, values for total villus population in the control animals in the present study (130000) compare favourably with earlier reports of 140000 villi in the adult Wistar rat small intestine (Clarke, 1972). This comparison suggests that adult numbers of villi may be reached within 3 weeks post-weaning.

Riboflavin deficiency interrupts the normal increase in villus number; a weaning value for villus number is still evident after 8 weeks on a deficient diet implying that an expansion of the villus population is halted rather than delayed in riboflavin deficiency, which may be of particular importance to absorption. A failure to reach normal villus number during the particularly active period of gastrointestinal development post-weaning may have longterm consequences and may contribute to the reduction in Fe absorption already reported in riboflavin deficiency (Powers et al. 1988, 1991).

We have already reported villus-cell hyperplasia in conjunction with an unaltered total mucosal DNA content after 5 weeks of feeding weanling rats on a riboflavin-deficient diet (Williams et al. 1995). The association between riboflavin deficiency and lower villus number in the duodenum explains villus-cell hyperplasia in the absence of increased mucosal DNA.

The results of the current experiment strongly support the original proposal that 
riboflavin deficiency alters the cytokinetics of the small intestine (Powers et al. 1993). An increased proliferative activity within the crypt of riboflavin-deficient rats has already been demonstrated (Powers et al. 1993). The current results show an approximate twofold increase in the rate of cell transit from the crypt and along the villi in the riboflavin-deficient group. As the absorptive function of the intestine is determined by the maturity and number of enterocytes (Goodlad \& Wright, 1990), the balance between influx of cells onto the villus, rate of cell differentiation and loss of cells from the villus tip is critical to the absorptive capacity of the small intestine. We would predict that an increased transit rate of enterocytes along the villus would be associated with an increased rate of exfoliation of cells from the villus tip. The function of the villus would be jeopardized since cells are unlikely to complete their maturation before being exfoliated into the lumen. It seems likely therefore that the effect of riboflavin deficiency on the cytokinetics of the small intestine may, at least in part, be responsible for the decreased absorption and increased rate of $\mathrm{Fe}$ loss seen in riboflavin deficiency (Powers et al. 1991). We suggest that increased crypt depth (Powers et al. 1993) and villus length (Williams et al. 1995) seen after 5 weeks of riboflavin depletion are an adaptatory response to an increased crypt-cell production rate and increased rate of cell transit, thereby increasing the absorptive cell population and increasing the likelihood of these cells reaching functional maturity before exfoliation from the villus tips. These structural changes may not fully compensate for the cytokinetic changes since absorption of $\mathrm{Fe}$ is reduced after 7 weeks of feeding young rats on a riboflavin-deficient diet (Powers et al. 1988).

In conclusion, riboflavin deficiency has profound effects on small-intestinal cytokinetics and morphology. There is a failure to reach adult numbers of villi which is initially reflected in a decreased total mucosal DNA. Cell hyperplasia resulting in increased crypt and villus dimensions may correct the deficit in the mucosal-cell population. Villus and crypt hypertrophy as a result of cell hyperplasia would confer an obvious benefit if the rate of transit of enterocytes on the villus is increased. The current observations help to explain the altered $\mathrm{Fe}$ handling seen in riboflavin deficiency. An increased enterocyte transit rate would be expected to increase exfoliation from the villi and thereby contribute to the increased rate of gastrointestinal Fe loss. Fewer villi, coupled with a reduction in the life-span of the enterocyte, may explain the decreased rate of Fe absorption seen in riboflavin deficiency.

This work was supported by The Wellcome Trust $(035705 / Z)$.

\section{REFERENCES}

Bessey, O. A., Lowry, O. H. \& Love, R. H. (1949). The fluorimetric measurement of the nucleotides of riboflavin and their concentration in tissues. Journal of Biological Chemistry 180, 755-769.

Clarke, R. M. (1972). The effect of growth and fasting on the number of villi and crypts in the small intestine of the albino rat. Journal of Anatomy 112, 27-33.

Dowling, R. H. (1982). Small bowel adaptation and its regulation. Scandinavian Journal of Gastroenterology 74, 53-74.

Fairweather-Tait, S. J., Powers, H. J., Minski, M. J., Whitehead, J. \& Downes, R. (1992). Riboflavin deficiency and iron absorption in adult Gambian men. Annals of Nutrition and Metabolism 36, 34-40.

Forrester, J. M. (1972). The number of villi in the rat's jejunum and ileum: effect of normal growth, partial enterectomy and tube feeding. Journal of Anatomy 111, 283-291.

Goodlad, R. A. \& Wright, N. A. (1990). Changes in intestinal cell proliferation, absorptive capacity and structure in young, adult and old rats. Journal of Anatomy 173, 109-118.

Gratzner, H. G. (1982). Monoclonal antibody to 5-bromo and 5-iododeoxyuridine: a new reagent for detection of DNA replication. Science $218,474$.

Munro, H. N. \& Fleck, A. (1966). The determination of nucleic acids. In Methods of Biochemical Analysis, vol. 5, pp. 113-176 [D. Glick, editor]. New York: John Wiley.

Powers, H. J. (1987). A study of maternofetal iron transfer in the riboflavin-deficient rat. Journal of Nutrition 117, 852-856. 
Powers, H. J., Bates, C. J. \& Duerden, J. M. (1983). Effects of riboflavin deficiency on some aspects of iron metabolism. International Journal for Vitamin and Nutrition Research 53, 371-376.

Powers, H. J., Weaver, L. T., Austin, S. \& Beresford, J. K. (1993). A proposed intestinal mechanism for the effect of riboflavin deficiency on iron loss in the rat. British Journal of Nutrition 69, 553-561.

Powers, H. J., Weaver, L. T., Austin, S., Wright, A. J. A. \& Fairweather-Tait, S. J. (1991). Riboflavin deficiency in the rat: effects on iron utilization and loss. British Journal of Nutrition 65, 487-496.

Powers, H. J., Wright, A. J. A. \& Fairweather-Tait, S. J. (1988). The effect of riboflavin deficiency in rats on the absorption and distribution of iron. British Journal of Nutrition 59, 381-387.

Williams, E. A., Powers, H. J. \& Rumsey, R. D. E. (1995). Morphological changes in the rat small intestine in response to riboflavin depletion. British Journal of Nutrition 73, 141-146.

Williamson, R. C. N., Chir, M., Bucnholtz, T. W. \& Malt, R. A. (1978). Humoral stimulation of cell proliferation in small bowel after transection and resection in rats. Gastroenterology 75, 249-254.

Wimber, D. R. \& Lamberton, L. F. (1963). Cell population studies on the intestine of continuously irradiated rats. Radiation Research 18, 137-146.

Wynford-Thomas, D. \& Williams, E. D. (1986). Use of bromodeoxyuridine for cell kinetic studies in intact animals. Cell Tissue Kinetics 19, 179-182. 